\title{
RELATIONSHIP BETWEEN QUALITY IN ACCOUNTING INFORMATION AND ORGANIZATIONAL CHARACTERISTICS OF THE THIRD SECTOR ENTITIES
}

\author{
Relação entre a qualidade da informação contábil e as características \\ organizacionais das entidades do terceiro setor
}

\author{
Fernando M. Ramos* \\ Roberto Carlos Klann ${ }^{\star *}$
}

\begin{abstract}
This study intends to evaluate the relationship between the quality in accounting information and the organizational characteristics of Third Sector entities. The methodology is designed to follow a descriptive, documental and quantitative approach. The universe of the study is composed of Third Sector organizations, formally constituted in the Brazilian scenario. The target population has included organizations with OSCIP and UPF specifications. The 18,553 entities, which existed during the study, were investigated. The research used a probabilistic sample of 392 entities. The results indicate a predominance of the institutions established under the legal form of association. As for the size, the foundations are the larger ones. Regarding the quality of accounting information, we have identified a lower reported information quality index, when compared to the second sector. Finally, the results showed that the organizational characteristics of size, creation time and qualification as OSCIP have significant and positive influence on the quality of accounting information of the entities that we analyzed. This led to the conclusion that the non-profit organizations and regulatory organs need to make improvements regarding the accounting information reporting process, as well as the awareness of the importance of these reports for the decision-making process and public accountability. This study contributes to the discussion about the characteristics of the third sector organizations that relate with the quality of the accounting information reported by these institutions in the Brazilian scenario. It is the first study that analyzed this relationship in Brazil.
\end{abstract}

Keywords: Quality in Accounting Information. Third Sector. Accountability. Accounting in the Third Sector.

\section{RESUMO}

Esse estudo teve por objetivo avaliar a relação entre a qualidade da informação contábil e as características organizacionais das entidades do Terceiro Setor. Quanto ao delineamento metodológico, caracteriza-se como descritivo, documental e com abordagem quantitativa. 0 universo de estudo é composto pelas organizações do Terceiro Setor formalmente constituídas no cenário brasileiro. Como população-alvo definiu-se as organizações com qualificação de OSCIPS e UPF, que no momento da realização do estudo, totalizavam 18.553. Trabalhou-se com uma amostra probabilística de 392 entidades. Os resultados apontam uma predominância de instituições constituídas sob a forma legal de associação. Quanto ao tamanho, as fundações apresentam-se maiores. No que tange à qualidade da informação contábil, identificou-se um baixo índice de qualidade da informação reportada se comparada ao Segundo Setor. Por fim, os resultados apontaram que as características organizacionais de tamanho, tempo de constituição e qualificação como OSCIP possuem influência significativa e positiva sobre a qualidade da informação contábil das entidades analisadas. Conclui-se que as organizações sem fins lucrativos e órgãos regulamentadores precisam evoluir no processo de reporte da informação contábil, bem como na conscientização da importância desses relatórios para o processo de tomada de decisão e de prestação de contas públicas.

Palavras-chave: Qualidade da Informação Contábil. Terceiro Setor. Prestação de Contas. Contabilidade no Terceiro Setor.

\footnotetext{
* Professor of the Undergraduate Courses of Accounting and Business Administration of the Universidade do Contestado (UnC). PhD student in Accounting at the Universidade do Vale do Rio dos Sinos (Unisinos). Email: framos@unc.br. ORCID: 0000-0002-4222-1253

** Coordinator and Professor of the Graduate Program in Accounting of the Universidade Regional de Blumenau (FURB). PhD in Accounting and Business Administration by the Universidade Regional de Blumenau (FURB). Email: rklann@furb.br. ORCID: 0000-0002-3498-0938
} 


\section{INTRODUCTION}

W ith the changes in the prospects of research in accounting, in the mid-1980s, researchers began investigating accounting and the usefulness of accounting information in the context of non-profit organizations (CRUZ, 2010). The precursors of the research in the area are Weisbrod and Dominguez (1986), Tinkelman (1997) and Greenlee and Brown (1999).

The literature points to the accounting and financial reports as a communication tool between third sector organizations and stakeholders. A study by Falconer and Vilela (2001) showed that few third sector entities have published their financial reports with their guidelines for the management of the funds received. Cruz (2010) stresses that, within the national scenario, the research on accounting information quality of these entities is still little explored, since regulatory and disclosure issues are still precarious.

Several studies (BARTH; BEAVER; LANDSMAN, 2001; DECHOW; DICHEV, 2002; BARTH; LANDSMAN; LANG, 2008; LEE; MASULIS, 2009, MURCIA; SANTOS, 2009; ALMEIDA, 2010; LIMA, 2010; BEHN; DeVRIES; LIN, 2010; SAXTON; KUO; HO, 2011; CANG; CHU; LIN, 2014), show that factors such as size, time of creation, performance area, auditing firm and other characteristics may be related to the quality of accounting information that is generated and their disclosure. Thus, considering the paucity of studies in this area and the importance of disseminating quality information by the third sector entities, this research is concerned with the following issues: what is the relationship between the quality of accounting information disclosed and the characteristics of the third sector Brazilian entities? In order to answer that question, the researchers had as an objective to evaluate the relationship between the quality of accounting information disclosed and the characteristics of the third sector Brazilian entities.

In theory, this study, in addition to discussing the quality of accounting information, which is already widely studied in scientific circles, aims at addressing the phenomenon in a field which is not very explored. There are few studies on the third sector in Brazil and Latin America (CRUZ, 2010; SOARES, 2017). This demonstrates the originality of our research. In this context, the discussion about the third sector also becomes a contribution to understanding the determinants of the quality of financial reports in this research field.

The originality of the study consists in the investigation of the organizational characteristics related to the quality of the accounting information reported by the entities of the Brazilian third sector. This study is innovative, because it was the first study that analyzed this relationship in Brazil.

In the social sphere, to investigate third sector entities is of paramount importance due to the relevance of these organizations in the economic and social environment. To investigate the quality of accounting information of a non-profit organization is important for publicly traded entities. A large group of stakeholders, such as donors, government, society, employees, managers, suppliers and users are both concerned and desirous of having information about the entity's earnings. This investigation aims an understanding of their economic and financial performance. 


\section{THEORETICAL REFERENCES AND DEVELOPMENT OF ASSUMPTIONS}

Accounting, through its reports, should provide data and information that are useful for the decision processes, both internal and external to the organization, and it should also be reliable and provide the entity's actual numbers (MOST, 1977; IMHOF JR., 1992; HENDRIKSEN; VAN BREDA, 1999). Accounting information has quality when it is useful to both internal and external users of the organization, regardless of the expertise of those users (MOST, 1977). According to CPC 00 (CFC, 2012), the purpose of the accounting reports, in general, is to provide financial and accounting information about entities that are useful to current and potential investors of organizations, as well as creditors in general.

Hendriksen and Van Breda (1999) point out that besides being reliable, the information generated by accounting must be useful. Regarding the usefulness of accounting information, the Accounting Pronouncements Committee (CPC), through Technical Pronouncement CPC 00 (CFC, 2012, p.16), states that "if financial accounting information is to be useful, it must be relevant and represent with confidence what it proposes to represent. The usefulness of financial accounting information is increased, when it is comparable, verifiable, timely and understandable.

Barth, Beaver and Landsman (2001) and Barth et al. (2007) point out three important aspects of the quality of accounting information on entities. The first one refers to the fact that financial reports are prepared based on accounting standards that aim to faithfully represent the economic and financial situation of an organization. As a second aspect, compliance with standards adequately minimizes opportunistic and management actions. Third, the authors indicate that a better quality of accounting information is a reflection of less opportunistic errors in estimating the gains. Thus, these three aspects elevate accounting information to a higher level of quality, making it more relevant and useful to its users (LANG; RAEDY; YETMAN, 2003; LANG; RAEDY; WILSON, 2006; BARTH et al., 2007; BARTH; LANDSMAN; LANG, 2008).

However, for the accounting information of these entities to be relevant in the decision-making process, it should contain the following key quality characteristics of improvement: relevance, materiality, faithful representation, comparability, verifiability, timeliness and understandability (FASB, 2010; CFC, 2012). All qualitative features aim to provide useful information to users of accounting information. The useful accounting information is able to provide evidence to users that they are helpful in the decision-making process.

The main objective of financial statements within the third sector organizations is to provide information that meets the interests of external users. These are: (i) a mechanism that is able to provide information on the efficiency and effectiveness of services provided by these organizations; (ii) an assessment tool for the managers of the organizations; and (iii) suppliers of information to social investors, creditors and others about the prospects for cash flow and performance evaluation of these entities (FALK, 1992; KEATING; FRUMKIN, 2003; PARSONS, 2007; BEHN; DeVRIES; LIN, 2010; FASB, 2010; BEISLAND; MERSLAND, 2013).

Within the third sector, accounting financial reports should be seen from an accountability perspective, that is, as a tool to provide management accounts in relation to the 
funds obtained (FALK, 1992; KEATING; FRUMKIN, 2003; HAGER; POLLACK; RONNEY, 2001). These organizations have many stakeholders. They work both on the economic and financial aspects and on the quality of services and products offered. They also function to assure sustainability and operational continuity of these entities (BEISLAND; MERSLAND, 2013). Thus, it is of paramount importance that the accounting information provided be useful.

Studies analyzing the determinants of information quality of accounting point out that there is a relationship (positive/negative) between the characteristics of organizations both with a higher level of quality of accounting information and with the level of disclosure of the entities, in the context of private companies and non-profit organizations.

Studies on financial market entities demonstrate the existence of a relationship between the size and the level of accounting information quality and the level of disclosure (BALL; FOSTER, 1982; LANG; LUNDHOLM, 1993; BHOJARAJ; BLACCONIERE; D'SOUZA, 2004; DECHOW; GE; SCHARAND, 2010; HOLANDA et al., 2012; BRANDÃO et al., 2013). These studies show that larger organizations require greater level of control and, hence, better financial information. On the other hand, smaller organizations are more prone to deficiency in its internal controls. This aspect may cause the financial statements to not fairly reflect the economic and financial situation of the organizations (DOYLE; GE; McVAY, 2007; DECHOW; GE; SCHARAND, 2010).

Another strand, dedicated to non-profit organizations, points out that the size of the organizations also refers to the reputation of these entities. Larger organizations feel the need for professional management. Thus, the clear definition of its objectives, policies, procedures and actions that lead to the achievement of their social intentions, make the financial reports relevant for the analysis of stakeholders in these organizations. Moreover, these institutions are exposed to greater social and political pressure from its users (TRUSSEL; PARSONS, 2007; JEGERS, 2008; KITCHING, 2009; CRUZ, 2010). Within larger institutions, the costs of preparing financial information are easier to support (MURCIA; SANTOS, 2009). Based on these studies, we propose our first research hypothesis:

\section{H1 - The quality of accounting information is positively related to the size of the third sector entities.}

The time of constitution of entities, that also it can be called the age, is pointed as a reputation feature. This feature brings the connotation that the older the entities, the more experienced they are (CRUZ, 2010). Beisland and Mersland (2013) state that the time of constitution of organizations may affect the quality of accounting information, given that, over time, organizations will adopt practices and mechanisms leading to higher level of professionalism, ensuring that accounting reports are most useful to their users.

Thus, we have the second hypothesis of the study:

$\mathrm{H} 2$ - There is a positive relationship between the quality of accounting information and the time of constitution of the entities under analysis. 
The audit has as its primary function the examination of accounting records, ensuring the reliability of data provided by the entities. The completion of the audit ensures that the published financial statements are reliable, and faithfully represent both the equity and economic situation of the organizations. It also discloses the reliability of internal controls of an entity, thus ensuring higher quality of reported financial information (CARDOZO, 1989; POWER, 2003; JEGERS, 2008; PUYVELD et al., 2012). These authors argue that the audit of the financial statements of non-profit organizations ensures the highest level of reliability of financial data, making the accounting reports more reliable than those reports of the entities that are not audited by external auditors.

From that, we draw the third hypothesis of this research:

\section{H3 - Non-profit organizations having external audits show higher level of quality of accounting information.}

From the data collected through the survey and subsequent application of statistical techniques, one can accept or refute the above hypotheses. As for $\mathrm{H} 1$, we infer that the size of the entities influences the process of preparing the financial information and of improving the level of disclosure of information. This means that larger organizations tend to disclose more information than smaller ones, resulting in higher quality of the reported accounting information. Similarly, $\mathrm{H} 2$ would show that the time of an incorporation, that is, the experience of the entity, influences the disclosure level, which means that experienced entities have a tendency to have better quality score of accounting information. Regarding $\mathrm{H} 3$, it appears that audited non-profit organizations are inclined to have a higher level of disclosure and, thereby, the conduction of independent audit of the financial statements of non-profit organizations influence a higher level of the quality accounting information.

\section{METHODOLOGICAL DESIGN}

This research is defined as descriptive. It initially aims at assessing the quality of accounting information of Brazilian non-profit organizations. It later relates them to the characteristics of these entities. This is a documental research, in which, the financial statements and other financial reports are available for review.

The research also classifies itself as quantitative. It uses probabilistic methods in order to define the sample to be analyzed. It employs univariate statistical methods (average, minimum, maximum, standard deviation, Pearson correlation) in the analysis of the characteristics of the entities. Besides, it also uses multivariate ones (multiple linear regression) in order to analyze the influence of the characteristics of the entities of the third sector on the quality of accounting information.

\subsection{POPULATION AND SAMPLE}

The study's population consists of the third sector organizations officially incorporated in Brazil. These entities have certain characteristics in common. For instance, they 
pertain to the realization of this study and are consistent with the recommendations in the literature (SALAMON; ANHEIER, 1997). Due to the low rate of publication of the financial statements by the entities that make up the universe of this research, it was necessary to define the target population. Here, the total of qualified entities includes Organization of Civil Society of Public Interest - OSCIP and Federal Public Utility - UPF, which totaled 18,553 Brazilian institutions in October 2013. OSCIP and UPF are classified as targeted study, since they are required to both achieve accountability and present their financial statements to CNEs/MJ (National Registry of Public Utility Entities/ Justice Ministry).

After the population of the study is known, the definition of the sample to be analyzed is required. For Freitas et al. (2000), the best sample of a survey is representative of a population or a model of it. Thus, the sample of this study is probabilistic and randomly selected. For the sampling plan, we departed from the target population of 18,553 Brazilian institutions, with a degree of reliability of $95 \%$, which reaches a sample of 392 non-profit institutions.

The period of data collection and analysis is limited to the year 2012, because, at the time of the collection of data, the 2013 financial statements of entities registered with the CNE's public had not been published yet. In addition, the use of previous years is limited because there is no regularity of the financial statements by the entities of the third sector to the Ministry of Justice.

\subsection{COLLECTION AND ANALYSIS OF DATA}

The data collection for this study occurred in two stages. The first one captured the variables used to characterize the institutions. The second collected the financial statements for measuring the quality index of financial information of the entities in the sample. Table 1 shows the variables used within their operation, classification, location and the database used.

In order to measure the accounting information quality index of the Brazilian third sector entities analyzed, we used a checklist of items that was built from the General Technical Interpretation (ITG-2002) and ITG 1000. The research instrument used consists of 59 analysis criteria, subdivided into seven sections, aiming at capturing the level of disclosure of these entities. This check-list has already been used in a study by Ramos and Klann (2015).

In this research, the data collected are secondary because they are collected from financial statements presented on the website of CNEs/MJ, the Federal Revenue of Brazil and the entities themselves. Although the database $\mathrm{CNES} / \mathrm{MJ}$ is relatively new, it is unique on the national scene, as it defines itself as a disclosure mechanism of accounting information of third sector organizations in Brazil (CRUZ, 2010). Data analysis was performed in three steps, using both univariate and multivariate statistical techniques. The first step consisted in the characterization of the institutions by means of descriptive statistical measures, such as average, minimum, maximum and standard deviation of the following characteristics: size, area of operation, creation time, audited organizations, legal form and the kind of certificate obtained. In the second moment, the quality of accounting information of these 
entities was evaluated through the disclosure index, resulting in an indicator, also analyzed by means of descriptive statistics.

Table 1 - Variables Used

\begin{tabular}{|c|c|c|c|c|c|}
\hline \multicolumn{2}{|c|}{ Variables } & Operationalization & Rating & Localization & DataBase \\
\hline \multicolumn{2}{|c|}{$\begin{array}{l}\text { Quality of Accounting Infor- } \\
\text { mation Index (IQIC) }\end{array}$} & $\begin{array}{l}\text { Check-list with } 59 \text { questions } \\
\text { showing information in the } \\
\text { financial statement of the } \\
\text { entities, with binary answer, } \\
\text { assigning } 1 \text { to highlighted items } \\
\text { and } 0 \text { to non highlighted items. }\end{array}$ & Dependent & $\begin{array}{l}\text { Accounting State- } \\
\text { ments }\end{array}$ & CNEs/MJ \\
\hline \multicolumn{2}{|c|}{ Size (logTAM) } & Size $=\log$ of Total Assets & \multirow{3}{*}{ Independent } & \multirow{7}{*}{$\begin{array}{l}\text { National Registry } \\
\text { of Legal Entities. } \\
\text { Report CNEs/MJ }\end{array}$} & CNEs/MJ \\
\hline \multicolumn{2}{|c|}{$\begin{array}{l}\text { Constitution Time } \\
(\operatorname{logTCONST})\end{array}$} & $\begin{array}{c}\text { Age }=\text { log of the difference bet- } \\
\text { ween the current year and the } \\
\text { date of the foundation. }\end{array}$ & & & $\begin{array}{c}\text { Bureau of Internal } \\
\text { Revenue }\end{array}$ \\
\hline \multicolumn{2}{|c|}{ Audit (AUD) } & $\begin{array}{l}\text { AUD }=(1) \text { Audited; } \\
\quad(0) \text { Non-audited }\end{array}$ & & & CNES/MJ \\
\hline \multirow[t]{2}{*}{$\begin{array}{l}\text { Legal Form } \\
\text { (FORML) }\end{array}$} & $\begin{array}{l}\text { Association } \\
\text { (ASSOC) }\end{array}$ & $\begin{array}{l}\text { ASSOC }=(1) \text { Association; } \\
(0) \text { Foundation }\end{array}$ & \multirow{4}{*}{$\begin{array}{l}\text { Control } \\
\text { Variables }\end{array}$} & & $\begin{array}{c}\text { Bureau of Internal } \\
\text { Revenue }\end{array}$ \\
\hline & $\begin{array}{c}\text { Foundation } \\
\text { (FUND) }\end{array}$ & $\begin{array}{l}\text { FUND }=(1) \text { Foundation; } \\
(0) \text { Association }\end{array}$ & & & \\
\hline \multirow[t]{2}{*}{$\begin{array}{l}\text { Certification } \\
\quad(\text { CERT })\end{array}$} & $\begin{array}{l}\text { OSCIP } \\
\text { (OSCIP) }\end{array}$ & $\begin{array}{l}\text { OSCIP }=(1) \text { OSCIP; } \\
\quad \text { (0) Other }\end{array}$ & & & \multirow[t]{2}{*}{$\begin{array}{c}\text { Bureau of Internal } \\
\text { Revenue }\end{array}$} \\
\hline & UPF(UPF) & UPF $=(1)$ UPF; (0) Othera & & & \\
\hline
\end{tabular}

Source: Developed by the author (2014).

Both the third and the final stages tested the hypotheses of the research, from the Pearson correlation and multiple linear regression technique. In order to test the hypotheses of this research, the statistical tests of Pearson's Correlation and Multiple Linear Regression were used. Pearson's correlation test identifies the relationship between the quality of accounting information and the size, time of incorporation, audit performance in the financial statements, as well as the type of certification and the legal form of the entities. The multiple linear regression test allows to analyze the influence of these characteristics on the IQIC.

To analyze the influence of the characteristics in the IQIC, a multiple linear regression model is suggested, in which the IQIC is the dependent variable, and the variables $\log$ TAM, logTCONST and AUD are independent or predictive variables. It should be observed that for the TAM and TCONST variables, the logarithms of the values were used for data normalization purposes. The legal form of constitution and the title of these entities are used only as control variables.

For that, the achievement of the assumptions regression testing was required. In order to identify the normality of the data, the Kolmogorov-Smirnov test was performed; for the analysis of multicolinearity, the test Variable Inflator Factor (VIF) was applied; for the 
analysis of homoscedasticity, Levene's test was used; the autocorrelation of residues through the Durbin-Watson test was also analyzed.

In order to conduct the multiple linear regression, an econometrist model was designed. The proposed model considers logTAM, logTCONST, AUD, ASSOC, FUND, OSCIP, UPF as IQIC predicting variables. Then, the following regression equation was used:

$$
\mathrm{IQIC}=\beta 1 * \log \mathrm{TAM}+\beta 2 * \log \mathrm{TCONST}+\beta 3 * \mathrm{AUD}+\beta 4 * \mathrm{ASSOC}+\beta 5 * \mathrm{OSCIP}+\varepsilon
$$

\section{DISCUSSION AND ANALYSIS OF RESULTS}

\subsection{CHARACTERIZATION OF THIRD SECTOR ENTITIES}

All non-profit organizations analyzed in this research are composed of $91.84 \%$ of entities, included in legal terms as associations, and $8.16 \%$ as foundations. These data indicate a legal characterization of the disparity among these entities, which is consistent with the reality of the universe of third sector entities. Other studies such as Silva et al. (2011), suggest a tendency of organizations to be established as associations instead of foundations, due to two aspects: (i) first, this form of institutionalization costs less, it is simples and does not have so many rules as the foundations; (li) finally, there is no need for asset al location.

As we showed above, the organizations are qualified as OSCIP or UPF. Thus, we found that approximately $52 \%$ of the organizations incorporated as associations are qualified as OSCIP. This certification predominates, while only about $48 \%$ of the associations qualify themselves as UPF. However, when the context of the foundations is considered, the situation becomes reversed, i.e., only $31.25 \%$ hold the title of OSCIP, while $68.75 \%$ are classified as UPF.

Table 2 shows the descriptive statistics about the size of the associations and the private foundations analyzed, measured through the total assets of the organizations.

Table 2 - Size of the Organizations

\begin{tabular}{cccc}
\hline & Global & Association & Foundation \\
\hline Minimum & 6.61 & 6.61 & $1,299.00$ \\
Maximum & $638,936,140.24$ & $638,936,140.24$ & $106,902,623.00$ \\
Average & $5,974,072.52$ & $5,585,962.41$ & $10,340,311.18$ \\
Median & $275,753.62$ & $259,248.65$ & $679,298.65$ \\
Standard Deviation & $36,136,765.24$ & $38,490,169.69$ & $24,118,913.78$ \\
\hline
\end{tabular}

Source: Research Data (2014).

Table 2 shows that the entity's greatest asset is established as an association, with total assets of $\mathrm{R} \$ 638.936 .140,24$, while the largest foundation has assets of $\mathrm{R} \$ 106.902 .623,00$. It is also observed that the average total assets of the entities is $\mathrm{R} \$ 5.974 .072,52$. This average is similar to that found among associations. However, in 
the context of the foundations, it is $\mathrm{R} \$ 10.340 .311,18$. The fact that the foundations show themselves larger is perhaps linked to the founders' need to integrate the patrimony at the time of setting up these organizations.

Besides the size, the time of creation of the organizations has also been described in the literature as related to organizational reputation. Regarding the constitution of time, authors such as Doyle, Ge and McVay (2007), and Beisland and Mersland (2013) suggest that the greatest operating time of an entity leads it to draw conclusions from situations previously experienced. This leads to the acquisition of experience and development of internal controls.

Table 3 shows the number of entities by constitution-time group.

Table 3 - Rating regarding time of constitution

\begin{tabular}{ccccccc}
\hline \multirow{2}{*}{ Age } & \multicolumn{2}{c}{ Association } & \multicolumn{2}{c}{ Foundation } & \multicolumn{2}{c}{ Total } \\
\cline { 2 - 7 } & $\mathbf{N}$ & $\%$ & $\mathbf{N}$ & $\%$ & $\mathbf{N}$ & $\%$ \\
\hline From 0 to 10 years & 115 & 31.94 & 5 & 15.63 & 120 & 30.61 \\
From 11 to 20 years & 128 & 35.56 & 13 & 40.63 & 141 & 35.97 \\
From 21 to 30 years & 66 & 18.34 & 9 & 28.12 & 75 & 19.14 \\
From 31 to 40 years & 26 & 7.22 & 2 & 6.25 & 28 & 7.14 \\
Over 40 years & 25 & 6.94 & 3 & 9.37 & 28 & 7.14 \\
Total & 360 & 100 & 32 & 100 & 392 & 100 \\
\hline
\end{tabular}

Source: Research Data (2014).

According to Table 3, most of the entities have the constitution time between 11 to 20 years, corresponding to $36 \%$ of the analyzed entities. The entities between 0 to 10 years show a percentage of $30.6 \%$ stake. This information is consistent with those data presented by the census conducted by IBGE (2012), according to FASFIL. The data show that $51 \%$ of the entities were created between the years 1991-2005.

Based on what was recommended in the study by IBGE (2012), in addition to the data obtained in this study, one can possess two observations about this sector in Brazil: (i) firstly, there was an expansion of the entities in the last two decades, since its presence in previous decades is smaller; finally, (ii) one may be experiencing a difficulty in sustaining these institutions over the years.

Nonprofit organizations, regardless of the operating area, must meet the demands from their users to generate reliable accounting and financial reports. Regarding this, the audit is an instrument to ensure the reliability of disclosed reports. Among the analyzed entities, it was identified that only $38.38 \%$ of organizations reported conduct independent audit of its financial statements, representing 13 foundations and 139 associations. An additional information is the number of entities that perform the audit. They are $40.13 \%$ of qualified entities as OSCIP, and $59.87 \%$ as UPFs.

After the analysis of the variables that account for the characterization of the entities that make up the sample, the analysis of the quality of accounting information of nonprofit Brazilian organizations is presented through the disclosure level. 


\subsection{QUALITY SCORE OF ACCOUNTING INFORMATION}

The accounting disclosure in the context of non-profit organizations is very important because it is through accounting reports that the entities may account for and disclose important information on their economic, financial and operating situation. Table 4 shows the descriptive statistics about the quality index of accounting information of entities, which was determined after the analysis of the disclosure of the items was analyzed.

Table 4 - Descriptive Statistics of the Accounting Information Quality Index

\begin{tabular}{|c|c|c|c|c|}
\hline \multicolumn{5}{|l|}{ Panel A - Descriptive Statistics IQIC } \\
\hline & Average & Minimum & Maximum & $\begin{array}{l}\text { Standard } \\
\text { Deviation }\end{array}$ \\
\hline IQIC & $32.4 \%$ & $10 \%$ & $54 \%$ & $7.94 \%$ \\
\hline \multicolumn{5}{|c|}{ Panel B - Descriptive Statistics of IQIC by Practice Area } \\
\hline & Average & Mínimum & Maximum & $\begin{array}{l}\text { Standard } \\
\text { Deviation }\end{array}$ \\
\hline Social Assistence & $32 \%$ & $15 \%$ & $47 \%$ & $7 \%$ \\
\hline Culture & $31 \%$ & $10 \%$ & $54 \%$ & $10 \%$ \\
\hline Development and Defense of Rights & $33 \%$ & $10 \%$ & $53 \%$ & $9 \%$ \\
\hline Education & $33 \%$ & $10 \%$ & $47 \%$ & $7 \%$ \\
\hline Housing & $34 \%$ & $34 \%$ & $34 \%$ & - \\
\hline Environment and Animal Protection & $31 \%$ & $12 \%$ & $49 \%$ & $11 \%$ \\
\hline Religion & $34 \%$ & $24 \%$ & $42 \%$ & $9 \%$ \\
\hline Health & $34 \%$ & $22 \%$ & $51 \%$ & $6 \%$ \\
\hline \multicolumn{5}{|c|}{ Panel C - Descriptive Statistics of IQIC by Legal Form } \\
\hline & Average & Minimum & Maximum & $\begin{array}{l}\text { Standard } \\
\text { Deviation }\end{array}$ \\
\hline Association & $32 \%$ & $10 \%$ & $54 \%$ & $8 \%$ \\
\hline Foundation & $35 \%$ & $10 \%$ & $46 \%$ & $7 \%$ \\
\hline \multicolumn{5}{|c|}{ Panel D - Descriptive Statistics of IQIC by Qualification } \\
\hline & Average & Minimum & Maximum & $\begin{array}{l}\text { Standard } \\
\text { Deviation }\end{array}$ \\
\hline OSCIP & $30 \%$ & $10 \%$ & $51 \%$ & $8 \%$ \\
\hline UPF & $35 \%$ & $20 \%$ & $54 \%$ & $7 \%$ \\
\hline
\end{tabular}

Source: Research Data (2014)

The analysis of the accounting information quality index (IQIC) identifies a worrying situation. This has to do with the fact that the highest level found was $54 \%$. This means that entities disclose only slightly more than half of the items required by regulatory bodies entities. Compared with studies such as those by Lima (2010) and Gabriel and Silveira (2011), which also used a disclosure index to measure the quality of accounting information with non-profit entities, it can be said that the information quality accounting of non-profit Brazilian entities falls short. 
The average disclosure determined in this study was $32.40 \%$ and the minimum was 10\%. However, studies by Lima (2010) and Gabriel and Silveira (2011) on the financial market have demonstrated average indexes of $64.82 \%$ and $67.17 \%$, respectively. The lowest rates of disclosure in these studies were $62.62 \%$ and $29.17 \%$, respectively. These data indicate that the third sector entities have lower IQIC when compared to the entities of the second sector.

When we analyzed IQIC by area of activity, it was found that only three areas of entities had index higher than $50 \%$ of the analyzed items. These are Culture (54\%), Development and Defense of Rights (53\%) and Health (51\%). The areas Housing and Religion had the lowest rates. This difference perhaps is linked to the fact that usually entities associated with the promotion of culture are related to the edicts of fostering culture, which leads them to the fulfillment of specific rules and the accountability of funds to specific organs.

Through the analysis of the data classified according to the legal form of the entities, one can understand that the foundations have disclosure level slightly higher than the associations, with average rate of disclosure of $35 \%$ against $32 \%$ of the associations. This result is plausible, since the foundations are run by stricter rules than the associations. The foundations are made of a public deed, called Statute. They must obtain operating permits from the Public Ministry (MP) and should report annually to the state headquarters of the MP. They must also report any changes related to their operational and financial aspects. It is worth remembering that the obligation to provide annual accounts is determined both by art. 66 of the Civil Code and the sanction of normative acts, which are prescribed by the MP of each Brazilian state.

Overall, the indexes show a low level of accounting information quality for Brazilian entities. $98.72 \%$ of the investigated entities showed less than $50 \%$ of the items that should be disclosed, determined by accounting standards as required for accounting information. This report is useful in the decision-making process of social investors, creditors, managers, government and other stakeholders in these entities.

\subsection{RELATIONSHIP BETWEEN THE QUALITY OF ACCOUNTING INFORMATION AND ORGANIZATIONAL CHARACTERISTICS}

As the main focus of this study is to evaluate the relationship between organizational characteristics and the quality of accounting information of third sector entities, we initially performed the Pearson correlation test. This, aimed the analysis of the relationship among variables: assets, creation time, independent audit engagement, legal form and certification with the quality score of accounting information identified in the analyzed entities. Table 5 shows the results of the test performed.

The result of the correlation test showed in Table 5 indicates a positive and significant relationship $(p<0.01)$ between the quality of accounting information and these characteristics: size, creation time, audit and the organizations certified as OSCIPS.

The correlation between the quality index of accounting information and the size demonstrates that larger entities have a higher level of quality of financial reports. This result converges with the studies carried out with financial market institutions (BALL; FOSTER, 
1982; LANG; LUNDHOLM, 1993; BHOJARAJ; BLACCONIERE; D'SOUZA, 2004; DECHOW; GE; SCHARAND, 2010; HOLANDA et al., 2012; BRANDÃO et al., 2013). The result shows that more experienced non-profit Brazilian organizations are better able to present financial information, as these tend to have higher experience to deal with the reports and accounting figures.

Table 5 - Pearson Correlation Test

\begin{tabular}{|c|c|c|c|c|c|c|c|c|c|}
\hline & & IQIC & TAM & TCONST & AUD & ASSOC & FUND & OSCIP & UPF \\
\hline \multirow{2}{*}{ IQIC } & Correl & 1 & $.499 * *$ & $.334^{* *}$ & $.307 * *$ & -.090 & .090 & $.270 * *$ & $-.270 * *$ \\
\hline & $\mathbf{N}$ & 392 & 392 & 392 & 392 & 392 & 392 & 392 & 392 \\
\hline \multirow{2}{*}{$\operatorname{logTAM}$} & Correl & & 1 & $.420 * *$ & $.535^{* *}$ & $-.116^{\star}$ & $.116^{*}$ & $.200 * *$ & $-.200 * *$ \\
\hline & $\mathbf{N}$ & & 392 & 392 & 392 & 392 & 392 & 392 & 392 \\
\hline \multirow{2}{*}{ logTCONST } & Correl & & & 1 & $.322^{* *}$ & -.092 & .092 & $-.608 * *$ & $.608^{* *}$ \\
\hline & $\mathbf{N}$ & & & 392 & 392 & 392 & 392 & 392 & 392 \\
\hline \multirow{2}{*}{ AUD } & Correl & & & & 1 & -.011 & .011 & $.157^{* *}$ & $-.157 * *$ \\
\hline & $\mathbf{N}$ & & & & 392 & 392 & 392 & 392 & 392 \\
\hline \multirow{2}{*}{ ASSOC } & Correl & & & & & 1 & $-1.000 * *$ & $.112^{*}$ & $-.112^{\star}$ \\
\hline & $\mathbf{N}$ & & & & & 392 & 392 & 392 & 392 \\
\hline \multirow{2}{*}{ FUND } & Correl & & & & & & 1 & $-.112^{*}$ & $.112^{\star}$ \\
\hline & $\mathbf{N}$ & & & & & & 392 & 392 & 392 \\
\hline \multirow{2}{*}{ OSCIP } & Correl & & & & & & & 1 & $-1.000 * *$ \\
\hline & $\mathbf{N}$ & & & & & & & 392 & 392 \\
\hline \multirow{2}{*}{ UPF } & Correl & & & & & & & & 1 \\
\hline & $\mathbf{N}$ & & & & & & & & 392 \\
\hline
\end{tabular}

Subtitle: IQIC - Index of quality of accounting information; logTAM - log of Size; logTCONST - log of time of constitution; AUD - Audited Organization; ASSOC - Association; FUND - Foundation; OSCIP; UPF.

Source: Research Data (2014).

In addition to these variables, the quality index of accounting information relates positively to OSCIPs and negatively to UPFs. These results show that there is difference in the quality of accounting information according to the type of certificate received by non-profit entities. In addition, the entities qualified as OSCIPs are positively related to an audit, something that may explain the positive relationship between this title and IQIC. Art. 4 of Law no. 9.790/99 provides that the entities qualified as OSCIPs should hire independent auditors to perform the audit of its financial statements and, if necessary, also of the funds from the partnership agreement, which justifies the identified relationships.

In Table 5, one may also observe a positive relationship between size, audit and time of creation. This phenomenon suggests that larger organizations are more experienced and are the ones tending to contract/perform independent audit of their financial statements.

After performing the correlation test, the results of multiple linear regression tests are presented, with the five proposed models of equations, as shown in Table 6. 
Table 6 - Multiple Linear Regression - Model 1

\begin{tabular}{lcccc}
\hline \multicolumn{1}{c}{ Variables } & Beta & T & Sig. & VIF \\
\hline (Constant) & & 7,613 & 0 & \\
CONSTITUTION & 0,126 & 2,588 & 0,01 & 1,874 \\
TIME (logTCONST) & & & & 1,575 \\
SIZE (IogTAM) & 0,44 & 7,982 & 0 & 1,427 \\
AUDIT (AUD) & 0,019 & 0,367 & 0,714 & 1,595 \\
OSCIP & 0,109 & 1,974 & 0,049 & 1,028 \\
Association (ASSOC) & $-0,04$ & $-0,91$ & 0,363 & 1,0 \\
\hline ANOVA & & & & \\
\hline $\mathrm{R}$ & 0,522 & & & \\
R2 & 0,272 & & & \\
Sig &, $000 \mathrm{~b}$ & & & \\
Durbin-Watson & 1,737 & & & \\
Test of Levene & 0,693 & & & \\
$\mathrm{~N}$ & 392 & & & \\
\hline
\end{tabular}

Source: Research Data (2014).

From Table 6, it is possible to point out that the first proposed model is significant, and independent variables can explain $27,2 \%$ of the variance in accounting information quality score. By means of the results of the model 1 test, it appears that three variables are significant: $\log$ TAM, logTCONST and OSCIP. This information is convergent with the correlation among the results shown in Table 6. However, it diverges in relation to the variable AUD, because the model proposed showed no significance. The variables FUND and UPF were excluded from the model. This can be explained, since these variables are mutually exclusive dummies, i.e. those that are not FUND are ASSOC and the entities that are not UPF are OSCIPS.

The variable AUD was not significant, with a $\beta$ coefficient of 0.019 in model. This fact shows little influence upon the analyzed context, even having presented significant correlation in the Pearson correlation test (Table 5 ). The beta $(\beta)$ correlation between the variables AUD and IQIC, although significant, is low (0.307).

The failure to influence the conduct of the audit on the quality of accounting information of third sector entities is contrary to the expectations of this study and the literature, which demonstrate its influence on the quality of accounting information. Nevertheless, it appears that this result converges with the study by Saxton, Kuo and Ho (2011). For these authors, this result demonstrates that using only the independent audit, exclusively as a form of governance, does not guarantee greater level of disclosure and, consequently, higher quality of reported financial information.

In the context of the second sector, the audit has been demonstrated in some studies, already cited as influential on the quality of accounting information. However, there are also studies (BAUWHEDE; WILLEKENS; GAEREMYNCK, 2003; JEONG; RHO, 2004; IATRIDIS, 2011) that did not identify a significant influence of this variable. According to 
these authors, the non-influence might be related to other factors, such as the change of audit firm and elements involving the quality of audit work.

In addition to the above variables, we emphasize that the title OSCIP was also significant in model. This aspect indicates a factor contributing to better quality of accounting information. This result might be linked to the fact that these organizations are larger, as identified in the correlation test. In addition, the legislation governing certificated organizations as OSCIPS predicts compulsory publication of financial statements. The performance of the audit of these statements and the terms of partnership can also help these entities show a higher level of quality of accounting information.

The influence of the qualifying title as OSCIP on the quality of accounting information reported by non-profit institutions is consistent with the study's results by Yetman and Yetman (2004). The authors suggest that the efforts of regulatory entities in higher level of control and monitoring make governance practices - adopted coercively - contribute to a minimization of opportunistic actions, errors and failures in the process of preparing and presenting the financial statements of non-profit organizations.

The results about the variables TAM and CONST converge with studies by Marcuello and Salas (2001), Yetman and Yetman (2004); Behn, DeVries and Lin (2010); Cruz (2010) and Beisland and Mersland (2013). In these studies, the variables showed explanatory power and significant influence upon the quality of accounting information. Thus, it appears that larger organizations have the need for better internal controls and require clearer information for the decision-making process. Similarly, over time, there is a wish of evolving internal controls in order to meet the needs arising from organizational activities, thus contributing to better quality of accounting information (BEISLAND; MERSLAND, 2013).

With this result, it is possible to accept the $\mathrm{H} 1$ of the study. $\mathrm{H} 1$ predicted a positive relationship between the size of non-profit organizations and the quality of accounting information. The $\mathrm{H} 2$ prescribed the existence of a positive relationship between the quality of accounting information and the time of constitution of the analyzed entities. The hypothesis can also be accepted because both the correlation test and regression test showed, respectively, a relationship and positive influence between the calculated IQIC and the time of establishment of the non-profit organizations analyzed.

The H3, which foresaw a positive relationship between nonprofit organizations that have external auditing and a higher level of quality of accounting information, can not be accepted. Although the results suggest that it is related positively to a better quality of accounting information, a low influence of only $1.3 \%$ was identified in the first model, and of $1.9 \%$ in model 5 , both not significant. It is worth mentioning that the influence of the audit on the quality of accounting information is not conclusive. It leaves room for further research to be carried out within the third sector. The literature provides orientation on other aspects related to the audit, as rotation of the audit firm and the audit by a BigFour (BAUWHEDE; WILLEKENS; GAEREMYNCK, 2003; JEONG, RHO, 2004; IATRIDIS, 2011). These factors can influence the quality of reported financial information. These data were not captured in this study. The next section presents the final remarks of the study and the recommendations for future research based on our findings. 


\section{CONCLUDING REMARKS}

The study aimed at evaluating the relationship between the quality of accounting information disclosed and the characteristics of the third sector Brazilian entities. As for the quality of information of financial reports released by the third sector organizations investigated, the main results point to a low level of accounting disclosure and, consequently, the low quality of accounting information disclosed by the Brazilian third sector organizations, compared to entities in the second sector.

Regarding the analysis of the relationship between the characteristics of the third sector entities and the quality of accounting information, it was found that the size and the time of establishment of the entities positively influence the quality of disclosed accounting information. Therefore, the largest and most experienced organizations tend to have better quality of accounting information disclosed, which may be linked to the existence of more efficient controls, better knowledge of norms and experience on how to handle the accounting processes. Moreover, it can be inferred that these entities must hold knowledge of the importance of accounting figures to the management process. In addition, the entity's classification as OSCIP also contribute to the improvement of the accounting information evidenced.

The results suggest that the legal form of a non-profit organization does not have influence on the quality of accounting information. This suggests that more bureaucratic processes in the formation of a foundation, and the obligation of accountability annually to the Public Ministry is not able to ensure the quality of the information provided. However, it was also observed that organizations formed as associations have no obligation to provide accounts, except those classified as UPF or OSCIP. Thus, this fact does not contribute to a higher level of the quality of accounting information.

These results also show that non-profit organizations and regulatory bodies need to evolve in the accounting information reporting process, as well as in the awareness of the importance of these reports for the decision-making process and public accountability.

The results of this study contribute to the elucidation of some factors as predictors for the quality of the accounting information of third sector entities. This research increases the panorama of the discussion of the quality of the accounting information in the studied context, and serves as a base for the development of research oriented to the management, accounting and its information in the context of the nonprofit organizations.

\section{REFERENCES}

ALMEIDA, J. E. F. Qualidade da informação contábil em ambientes competitivos. 2010. 188 f. Tese (Doutorado em Controladoria e Contabilidade) - Faculdade de Economia, Administração e Contabilidade, Universidade de São Paulo, São Paulo, 2010.

BALL, R.; FOSTER, G. Corporate financial reporting: a methodological review of empirical research. Journal of Accounting Research, v. 20, p. 161-234, 1982. 
BARTH, M. E.; BEAVER, W. H.; LANDSMAN, W. R. The relevance of the value relevance literature for financial accounting standard setting: another view. Journal of Accounting and Economics, v. 31, n.1-3, p. 77-104, 2001.

BARTH, M. E. et al. Accounting quality: International Accounting Standards and US GAAP. Working Paper. Stanford University and University of North Carolina, nov., 2007.

BARTH, M. E.; LANDSMAN, W. R.; LANG, M. International accounting standards and accounting quality. Journal of Accounting Research, v. 46, n. 3, p. 467-498, 2008.

BAUWHEDE, H. V.; WILLEKENS, M.; GAEREMYNCK, A. Audit firm size, public ownership, and firms' discretionary accruals management. The International Journal of Accounting, $v$. 38, p. 1-22, 2003.

BEHN, B.K.; DeVRIES; D.D.; LIN, J. The determinants of transparency in nonprofit organizations: an exploratory study. Advances in Accounting, Incorporating Advances in International Accounting, v. 26, n. 1, p. 6-12, 2010.

BEISLAND, L. A.; MERSLAND, R. Earnings quality in nonprofit versus for-profit organizations: evidence from the microfinance industry. Nonprofit and Voluntary Sector Quarterly, v. 20 , n. 10 , p. 1-20, 2013.

BHOJARAJ, S.; BLACCONIERE, W.; D'SOUZA, J. What determines corporate transparency? Journal of Accounting Research, v. 42, n. 1, p. 207-252, 2004.

BRANDÃO, I. F. et al. Fatores determinantes do disclosure de guidance das companhias listadas na BM\&FBovespa. Revista Contemporânea de Contabilidade, v. 10, n. 21, p. 87114, 2013.

CANG, Y.; CHU, Y.; LINS, T.W. An exploratory study of earnings management detectability, analyst coverage and the impact of IFRS adoption: evidence from China. Journal of Accounting and Public Policy, v. 33, n. 4, 2014.

CARDOZO, J. S. S. O papel do auditor na sociedade ou o que a sociedade espera do auditor. Revista do Conselho Regional de Contabilidade do Rio Grande do Sul, Porto Alegre, v. 18, n. 56, p. 44-52, 1989.

CONSELHO FEDERAL DE CONTABILIDADE. CFC. Pronunciamento Técnico CPC 00. Conceitual Básico - Estrutura Conceitual para Elaboração e Divulgação de Relatório Contábil-Financeiro. In: CONSELHO FEDERAL DE CONTABILIDADE. CFC. Pronunciamentos Técnicos 2012. Brasília, DF - 2013. Available at: <http://www.cpc.org.br/CPC/Documentos-Emitidos/Publicacoes-CPC>

CRUZ, C. O. A. A relevância da informação contábil para os investidores sociais privados de entidades do terceiro setor no Brasil: uma investigação empírica. 2010. 165 f. Tese (Doutorado em Controladoria e Contabilidade) - Faculdade de Economia, Administração e Contabilidade, Universidade de São Paulo, São Paulo, 2010.

DECHOW, P. M.; DICHEV, I. D. The quality of accruals and earnings: the role of accrual estimation errors. Accounting Review. v. 77, p. 35-59, 2002.

DECHOW, P.; GE, W.; SCHARAND, C. Understanding earnings quality: a review of the proxies, their determinants and their consequences. Journal of Accounting and Economics, $v$. 50, n. 2-3, p. 344-401, 2010. 
DOYLE, J.; GE, W. McVAY, S. Determinants of weaknesses in internal control over financial reporting. Journal of Accounting and Economics, v. 44, p. 193-223, 2007.

FALCONER, A. P.; VILELA, R. Recursos privados para fins públicos: as grantimakers brasileiras. São Paulo: Fundação Peirópolis, 2001.

FALK, H. Towards a framework for not-for-profit accounting. Contemporary Accounting Research. Toronto, v. 8, n. 2, p. 468-499, 1992.

FINANCIAL ACCOUNTING STANDARDS BOARD. FASB. Statements of financial accounting concepts $\mathbf{n}$. 2: qualitative characteristics of accounting information. FASB, 2010. Available at: <http://www.fasb.org>. Accessed Mar. 4, 2014.

FREITAS, H.; OLIVEIRA, M.; SACCOL, A. Z.; MOSCAROLA, J. O método de pesquisa survey. Revista de Administração. São Paulo, v. 35, n.3, p. 105-112, jul./set., 2000.

GABRIEL, F.; SILVEIRA, A.D.M.S. Qualidade da Informação Contábil e Análise de sua Relação com a Estrutura de Governança Corporativa das Firmas no Brasil. In: CONGRESSO USP DE CONTROLADORIA E CONTABILIDADE, 11, 2011, São Paulo. Anais eletrônicos... São Paulo: USP, 2011. CD-ROM.

GREENLEE, J. S.; BROWN, K. L. The impact of accounting information on contributions to charitable organizations. Nonprofit Management \& Leadership. Stanford, v. 13, p. 111 125, 1999.

HAGER, M. A.; POLLAK, T.; ROONEY, P. Variations in Overhead and Fundraising Efficiency Measures: The Influence of Size, Age, and Subsector. In: ANNUAL CONFERENCE OF THE ASSOCIATION FOR RESEARCH ON NONPROFIT ORGANIZATIONS AND VOLUNTARY ACTION. Miami: Arnova, 2001.

HENDRIKSEN, E. S.; VAN BREDA, M. F. Teoria da contabilidade. São Paulo: Atlas, 1999.

HOLANDA, A. P. et al. Determinantes do nível de disclosure em clubes brasileiros de futebol. Revista de Contabilidade do Mestrado em Ciências Contábeis da UERJ (online), Rio de Janeiro, v. 17, n. 1, p. 2-17, jan./abril, 2012.

IATRIDIS, G. E. Accounting disclosures, accounting quality and conditional and unconditional conservatism. International Review of Financial Analysis, v. 20, n. 2, p. 88-102, 2011.

IMHOFF JR., E. A. The relation between perceived accounting quality and economic characteristics of the firm. Journal of Accounting and Public Policy, v. 11, n. 2, p. 97-118, 1992.

INSTITUTO BRASILEIRO DE GEOGRAFIA E ESTATÍSTICAS. IBGE. As fundações e Associações sem fins lucrativos no Brasil - 2010. Instituto Brasileiro de Geografia e Estatísticas - IBGE: Rio de Janeiro, Série Estudos e Pesquisas Informações Econômicas n. 20, 2012. Available at: <ftp://ftp.ibge.gov.br/Fundacoes_Privadas_e_Associacoes/2010/fasfil.pdf>

JEGERS, M. Managerial economics of non-profit organizations. London: Routledge, 2008.

JEONG, S. W.; RHO, J. Big Six auditors and audit quality: the Korean evidence. The International Journal of Accounting, v. 39, p. 175-196, 2004.

KEATING, E. K.; FRUMKIN; P. Reengineering nonprofit financial accountability: toward a more reliable foundation for regulation. Public Administration Review, v. 63, n.1, Jan./Fev. 2003. 
KITCHING, K. Audit value and charitable organizations. Journal Accounting Public Police, v. 28, p. 510-524, 2009.

LANG, M.; LUNDHOLM, R. Cross-sectional determinants of analyst ratings of corporate disclosures. Journal of Accounting Research, v. 31, n. 2, p. 246-271, 1993.

LANG, M.; RAEDY, J.; YETMAN, M. How representative are firms that are cross-listed in the United States? An analysis of accounting quality. Journal of Accounting Research, v. 41, p. 363-386, 2003.

LANG, M.; READY, J.; WILSON, W. Earnings management and cross listing: are reconciled earnings comparable to US earnings? Journal of Accounting and Economics, v. 42, p. 255-283, 2006.

LEE, G.; MASULIS, R. W. Seasoned equity offerings: quality accounting information and expected flotation costs. Journal of Financial Economics, v. 92, p. 443-469, 2009.

LIMA, I. G. Índice de conformidade de evidenciação (ICE): uma aplicação. 2010. 133 f. Dissertação (Mestrado em Ciências Contábeis) - Fundação Escola de Comércio Alvares Penteado, São Paulo, 2010.

MARCUELLO, C.; SALAS, V. Nonprofit organizations, monopolistic competition and private donations: evidence from Spain. Public Finance Review. v. 29, p. 183-207, may, 2001.

MOST, K. Accounting theory. Ohio: Grind, Inc., 1977.

MURCIA, F. D. R.; SANTOS, A. Fatores determinantes do nível de disclosure voluntário de companhias abertas no Brasil. Revista de Educação e Pesquisa em Contabilidade, v. 3, n. 2, p. 72-95, 2009.

PARSONS, L. M. The impact of financial information and voluntary disclosures on contributions to not-for-profit organizations. Behavioral Research is Accounting. Sarasota, v. 19, p 179-196, 2007.

POWER, M. Auditing and the production of legitimacy. Accounting, Organizations and Society, v. 28, n. 4, p. 379-394, 2003.

PUYVELD, S.V. et al. The governance of nonprofit organizations: integrating agency theory with stakeholders and Stewardship theories. Nonprofit and Voluntary Sector Quarterly, v. 41, n. 3, p. 431-451, 2012.

RAMOS, F. M.; KLANN, R. C. Qualidade da Informação Contábil das Entidades do Terceiro Setor Brasileiras. Future Studies Research Journal, v. 7, p. 03-32, 2015

SALAMON, L. M.; ANHEIER, H. K. Defining the nonprofit sector: a cross-national analysis. Manchester: Manchester University Press, 1997.

SAXTON, G.D.; KUO, J.S.; HO, Y.C. The determinants of voluntary financial disclosure by nonprofit organizations. Nonprofit and Voluntary Sector Quarterly, v. 41, n. 6, p. 10511071, 2011.

SILVA, C. E. G. et al. Formas jurídicas no terceiro setor brasileiro: estatuto legal, evidências empíricas e formalismo. Caderno Gestão Pública e Cidadania. São Paulo, v. 16, n. 58, 2011. 
SOARES, S.V. Diga-me quantos te citam, e eu te direi quem és - Estudo sobre as citações no âmbito da pesquisa contábil brasileira. 2017. $281 \mathrm{f}$. Tese (Doutorado em Controladoria e Contabilidade) - Faculdade de Economia, Administração e Contabilidade, Universidade de São Paulo, 2017.

TINKELMAN, D. An empirical study of the effect of accounting disclosure upon donation to nonprofit organizations. 1997. Dissertation (Doctoral Program in Accounting) - Graduate School of Business Administration, New York University, 1997.

TRUSSEL, J. M.; PARSONS, L. M. Finances reporting factors affecting donations to charitable not-for-profit organizations. Advances in Accounting. Oxford, v. 23, p. 263-285, 2007.

WEISBROD, B. A.; DOMINGUEZ, N. D. Demand for collective goods in private nonprofit markets: can fundraising expenditures help overcome free rider behavior? Journal of Public Economics. Amsterdam, v. 30, n. 1, p.83-96. jun. 1986.

YETMAN, M. H.; YETMAN, R.J. The effects of governance on the financial reporting quality of nonprofit organizations. In: GOVERNANCE OF NOT-FOR-PROFIT ORGANIZATIONS CONFERENCE, 2004, New York. Federal Reserve Bank: New York, 2004. Available at: <https:// www.newyorkfed.org/medialibrary/media/research/conference/2004/governance_papers/ YetmanYetman.pdf $>$.

Submission date: $17 / 08 / 2016$.

Approval date: 07/05/2018.

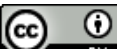

Creative Commons Atribuição 4.0 Internacional

Note: you can find this paper in Portuguese at http://www.revistaoes.ufba.br. 